\title{
Altered phospholipids in human rheumatoid synoviocytes
}

\author{
B. HENDERSON, L. BITENSKY, AND J. CHAYEN \\ From the Division of Cellular Biology, Kennedy Institute of Rheumatology, Bute Gardens, London W6 7 D
}

SUMMARY A specific cytochemical reaction for freely available phospholipids has shown a raised concentration of such phospholipids in the lining cells of human synovial membranes removed from rheumatoid joints. Quantitative measurement, by microdensitometry, of the amount of reaction $\vec{\omega}$ product per cell showed that the rheumatoid synoviocytes contained almost three times the amoung of free phospholipids present in the equivalent nonrheumatoid cells; statistically the difference was highly significant. Evidence from studies in which the bound phospholipids were 'unmasked ${ }_{.}^{\text {w }}$ by methanol-chloroform confirmed the view that the increased content of freely available phos $\vec{\pi}$ pholipids was related to altered lipid-protein binding rather than to an increase in total phospholipids:

There is considerable evidence that the membranes of the lining cells of human synovium from rheumatoid joints are different from those of nonrheumatoid synovium. The whole rheumatoid synovium is more permeable to plasma proteins (Sundblad et al., 1961; Nettelbladt et al., 1963); the synoviocytes show high activity of the membrane-bound enzyme 5'-nucleotidase (Farr et al., 1973), indicative of very permeable plasma membranes (Chayen et al., 1971b); and the synoviocytes have a high -SH:-S-Sratio consistent with a breakdown of protein crosslinkages (Butcher et al., 1973). Since many of the biological properties of both extracellular and intracellular membranes are determined by the state and degree of unsaturation of the phospholipids present in those membranes (Chapman and Quinn, 1976), it was clearly of some interest to investigate the nature of the phospholipids in nonrheumatoid and rheumatoid synoviocytes.

Analysis of the degree of unsaturation of fatty acids can be made cytochemically by the acid haematein reaction (Baker, 1946). This reaction has been shown to be specific for unsaturated doublebonds of fatty acids present in phospholipids (Chayen, 1968) and is normally controlled by bromination which saturates such bonds and renders them nonreactive. Moreover this reaction is capable of demonstrating the partial freeing of phospholipids from their binding with protein and this labilisation has been shown, in many instances, to be a delicate marker of cell damage (McCabe $e t$ al., 1965; Niles et al., 1966; Niles and Barnhouse, 1967).

Accepted for publication May 9, 1977

Correspondence to J. Chayen

\section{Materials and methods}

Biopsy specimens of human synovial membranes were taken at operation. The nonrheumatoi $\bar{F}$ specimens were taken from the knee, either from $\overrightarrow{0}$ quiescent joints or from otherwise normal joi htso after recent mechanical trauma, and were remoked during routine arthrotomy. The rheumatoid spe्दi mens were taken mainly from the knee duringo synovectomy from patients who had 'definite' on 'classical' disease according to the diagnostio criteria of the American Rheumatism Association? (Ropes et al., 1959). The Table gives details of the patients. All the specimens were taken in a bloodless

Table Specimens and patients studied

\begin{tabular}{|c|c|c|c|c|c|c|}
\hline \multicolumn{3}{|c|}{ Nonrheumatoid } & \multicolumn{4}{|l|}{ Rheumatoid } \\
\hline Specimen no. & Sex & Age (yrs) & Specimen no. & Sex & Age (yrs) & \\
\hline *1632 & $\mathbf{F}$ & 14 & 1565 & & & \\
\hline 1652 & $\mathbf{M}$ & 21 & 1571 & $\mathbf{F}$ & 46 & \\
\hline 1655 & $\mathbf{F}$ & 14 & 1582 & $\mathbf{F}$ & 55 & \\
\hline 1656 & $\mathbf{M}$ & 20 & 1599 & $\mathbf{F}$ & & \\
\hline * 1701 & $\mathbf{M}$ & 29 & 1626 & $\mathbf{F}$ & 43 & \\
\hline$* 1702$ & $\mathbf{M}$ & 60 & 1692 & $\mathbf{F}$ & 64 & \\
\hline 1704 & $\mathbf{F}$ & 17 & * 1696 & $\mathbf{F}$ & 24 & \\
\hline 1824 & $\mathbf{M}$ & & 1700 & $\mathbf{M}$ & 45 & \\
\hline *1837 & $\mathbf{M}$ & 21 & * 1705 & $\mathbf{F}$ & 54 & \\
\hline 1843 & $\mathbf{M}$ & 23 & 1709 & $\mathbf{F}$ & & \\
\hline 1869 & $\mathbf{M}$ & 16 & 1711 & $\mathbf{M}$ & 68 & \\
\hline 1877 & $\mathbf{M}$ & 23 & 1722 & $\mathbf{F}$ & 63 & \\
\hline 1916 & $\mathbf{M}$ & 12 & 1815 & $\mathbf{F}$ & 70 & \\
\hline *1935 & $\mathbf{M}$ & 23 & *1819 & $\mathbf{F}$ & 48 & $\sigma$ \\
\hline 1953 & $\mathbf{M}$ & 34 & 1928 & $\mathbf{F}$ & 68 & \\
\hline
\end{tabular}
*Comments: 1632 hyperplastic synovium containing demonstrable
iron. 1696 patient also suffering from psoriasis. 1701 2-yr history of joint trouble; osteochondritis in joint. 1702 2-yr history of joint trouble 1705 prednisolone $5 \mathrm{mg} /$ day. 1819 prednisolone $5 \mathrm{mg} /$ day. 1837 recent 
field but within 10 minutes of applying the tourniquet. Pieces of tissue, approximately $4 \mathrm{~mm}^{3}$, were chilled by precipitate immersion in $n$-hexane (BDH 'free from aromatic hydrocarbons' grade, boiling range $67-70^{\circ} \mathrm{C}$ ). After no more than one minute, each specimen was removed from the hexane and stored at $-70^{\circ} \mathrm{C}$ in a corked, dry glass tube. Specimens were then sectioned at $10 \mu \mathrm{m}$ in a Bright's cryostat maintained at a cabinet temperature of -25 to $-30^{\circ} \mathrm{C}$ with the knife cooled to $-70^{\circ} \mathrm{C}$ by packing its haft in solid carbon dioxide. The sections were transferred from the knife to slides which were at the ambient temperature of the laboratory, thus ensuring that the sections become flash-dried (Chayen and Bitensky, 1968). The methodology ensures that sections produced are free from ice damage. For each sample several sections were stained with toluidine blue to establish the precise histology.

Phospholipids were stained by the acid haematein method of Baker $(1946,1947)$ applied to fresh sections prepared as described above. As the acid haematein reaction stains phospholipids containing unsaturated bonds (i.e. double bonds), bromination was used as a control procedure. Sections were immersed in a saturated solution of bromine in distilled water for 24 hours, carefully washed, and then reacted in the normal acid haematein method. Phospholipids were unmasked by the method of Folch et al. (1951). Thus sections were treated with $1: 3(\mathrm{v} / \mathrm{v})$ methanol:chloroform for between 1 and 24 hours. After this treatment sections were reacted by the normal acid haematein procedure.

\section{QUANTIFICATION}

General chromation of the tissue section occurs using the acid haematein method, producing a nonspecific yellow or yellow-brown background colouration. The specific reaction of chromium with the tissue phospholipids involves a change in valency which permits the formation of a true 'lake' between the chromium and the haematein (Fieser and Fieser, 1953; Chayen, 1968). This specific reaction produces a blue or blue-black colouration. It has been shown (Henderson, 1977) that the spectral characteristics of the nonspecific background colouration show a progressive fall in absorption over the range $525-600 \mathrm{~nm}$, whereas the specific reaction has an absorption maximum at $550-575 \mathrm{~nm}$. In the section the specific-reaction colouration is overlaid on the nonspecific colouration. This problem of measuring a specific chromophore in the presence of nonspecific absorption such as 'scatter' is overcome in spectroscopy by subtracting a value for the latter from the total absorption (e.g. Kiefer, 1970). Thus to measure the specific reaction, measurements are made at $575 \mathrm{~nm}$ in synovial lining cells and 'control' measurements are made at the same wavelength but in nonresponsive tissue such as the collagenous stroma. Loveridge et al. (1974) have used a similar technique in their sensitive cytochemical bioassay of gastrin in which the nonspecific absorption is measured in the muscle close to the specifically responding parietal cells.

Fifteen to 20 synovial lining cells in each of two duplicate sections were measured at $575 \mathrm{~nm}$; a $\times 40$ objective was used with the smallest size of scanning spot $(0.5 \mu \mathrm{m}$ diameter $)$ and with the mask-size adjusted to accommodate one selected cell at a time. A similar number of readings were made in the adjacent collagenous stroma which showed only the nonspecific colouration. Subtraction of the mean absorption of each of these readings gave a value for the absorption (extinction) due to the specific reaction.

\section{STATISTICAL ANALYSIS}

Student's $t$ test was used to evaluate the results.

\section{Results}

MEASUREMENT OF FREE PHOSPHOLIPIDS

The acid haematein reaction was applied to sections from 15 specimens of rheumatoid and 15 specimens of nonrheumatoid synovial membrane. The cytoplasm of the rheumatoid synoviocytes was almost invariably stained darkly, showing the specific positive response to this reaction (Fig. 1). The nuclei were coloured yellow-brown with a positive reaction in nucleoli and chromocentres. Fibrin and, to a lesser extent, blood vessel walls, particularly those of small arterioles, also gave a positive reaction. However, the loose connective tissue underlying the synoviocytes showed only the nonspecific reaction. In contrast, again almost without exception, the cytoplasm of the nonrheumatoid synovial lining cells coloured only yellow or yellowbrown, as did the nuclei (Fig. 1).

Measurements of the specific reaction gave quantitative confirmation of these qualitative findings (Fig. 2). The mean and standard deviation of the intensity of the reaction in the 15 nonrheumatoid samples was $50 \pm 30$ units of relative absorption in contrast to $131 \pm 38$ for the 15 rheumatoid specimens. The variation in values recorded for each cell in any one specimen was $\pm 9 \%$. Thus there was nearly three times as much reaction in the rheumatoid as in the nonrheumatoid synovial lining cells; the difference was highly significant $(P<0 \cdot 001)$.

\section{MEASUREMENT OF BOUND PHOSPHOLIPIDS}

Sections from four specimens of rheumatoid and four of nonrheumatoid synovial membranes were 


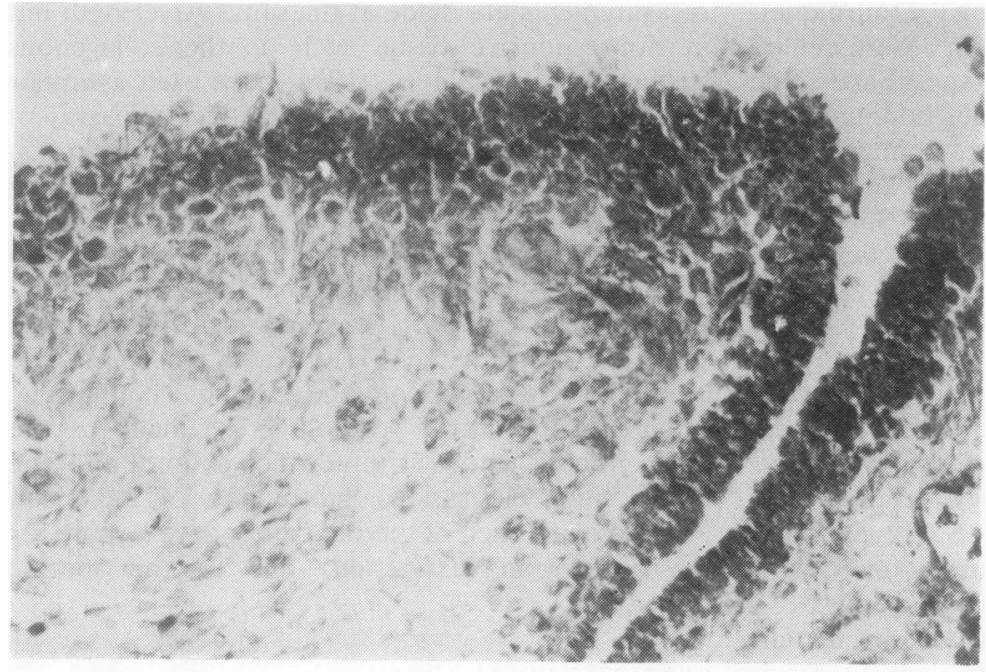

(a)

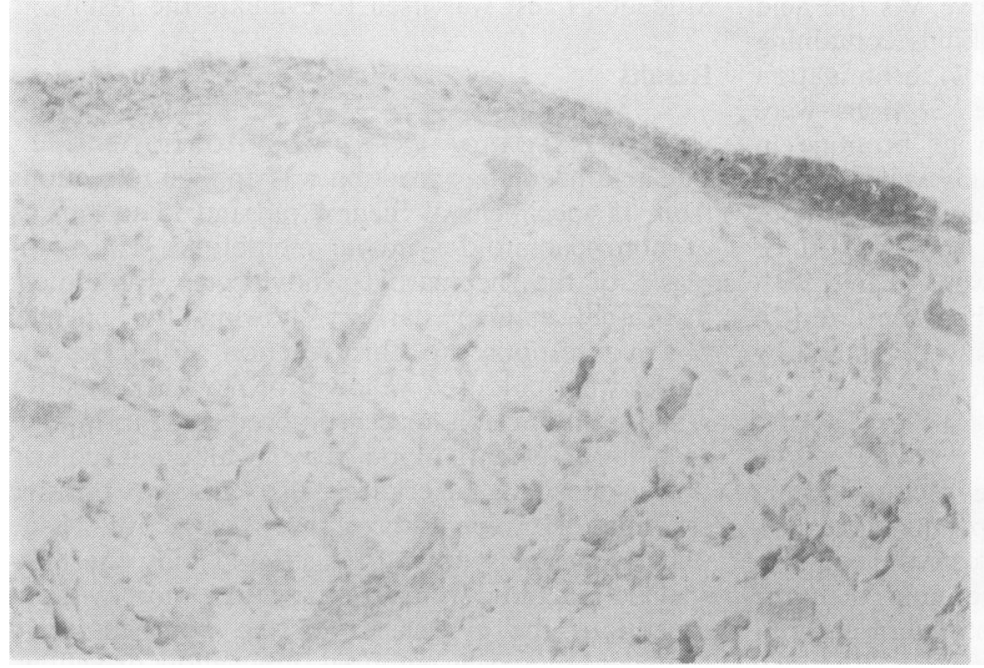

Fig. 1 The difference in the intensity of the acid haematein reaction in rheumatoid $(a)$ and nonrheumatoid (b) synoviocytes. $\times 200$.

(b)

subjected to $1: 3(\mathrm{v} / \mathrm{v})$ methanol-chloroform for 1,2 , 4,18 , or 24 hours to unmask phospholipids which were so strongly bound to protein that they could not react in the normal acid haematein test. After this treatment the sections were tested normally with the acid haematein reaction.

This unmasking procedure in nonrheumatoid synoviocytes caused a considerable increase in the reaction (Fig. 3). Specimens 1877, 1924, and 1953 showed a doubling of the available phospholipids after 1 hour in methanol-chloroform. The reaction was further increased in specimens 1877 and 1924 after 4 hours of treatment. In specimen 1701, which had an exceptionally high initial reaction, methanolchloroform acting for up to 2 hours removed some of this free phospholipid, but treatment for 24 hous increased the reaction about $40 \%$ above the hig initial value.

Qualitative microscopic examination of all thes sections showed that treatment with methanof. chloroform caused both the cytoplasm and the nucleus to stain with the specific grey-black reaction. In contrast, in sections of rheumatoid synovia membrane short periods of exposure to methanow chloroform decreased the reaction, or had litte effect except in specimen 1819 where a slight rise was observed (Fig. 4).

Other serial sections of all these specimens were subjected to bromination after treatment witp methanol-chloroform and before the acid haemateig 


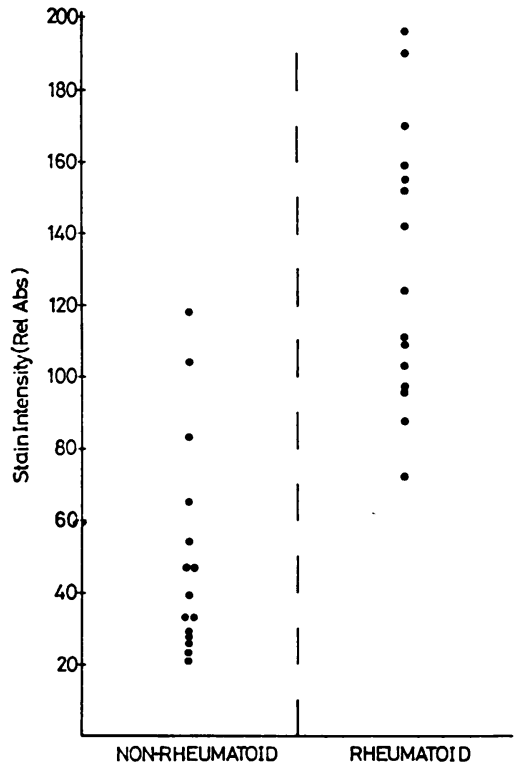

Fig. 2 Intensity (relative absorption/cell) of the positive acid haematein stain in rheumatoid and nonrheumatoid synoviocytes.
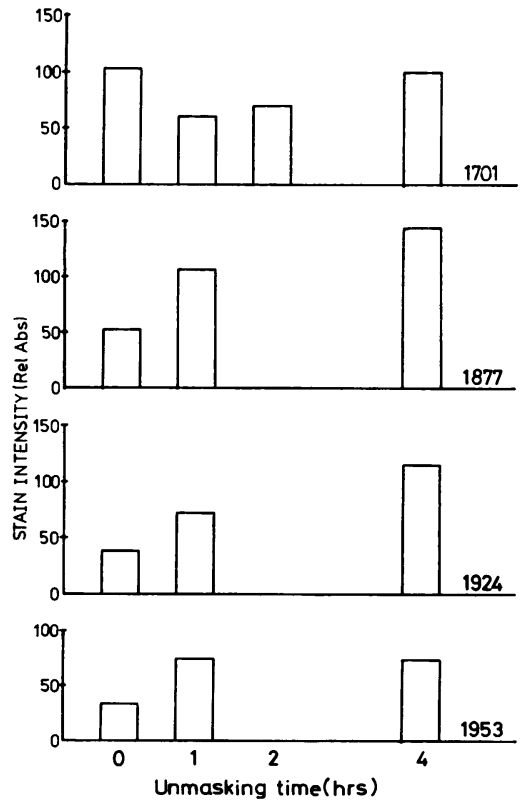

Fig. 3 Effect of prolonged times of unmasking by methanolchloroform on the acid haematein staining in nonrheumatoid synoviocytes.
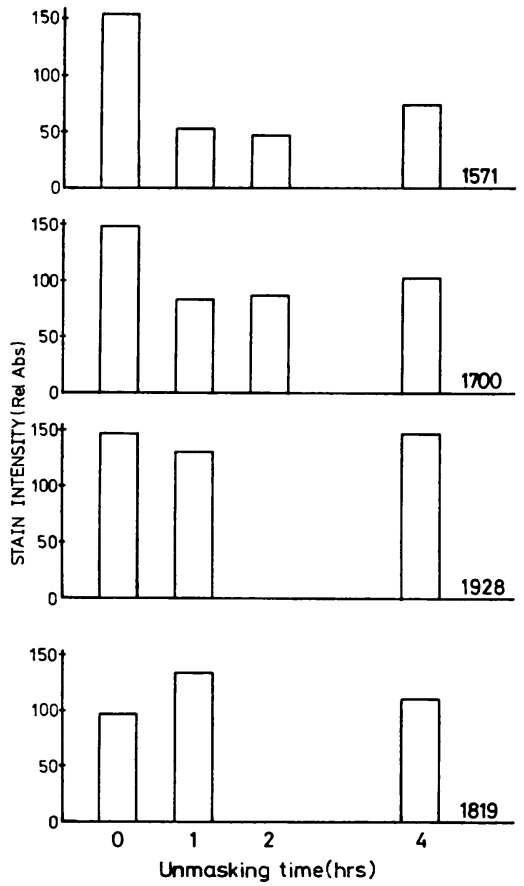

Fig. 4 Effect of prolonged times of unmasking by methanol-chloroform on the acid haematein staining in rheumatoid synoviocytes.

reaction. All showed obliteration of the specific reaction, indicating that the positive reaction was indeed due to unsaturated phospholipids.

\section{Discussion}

Baker's (1946) acid haematein method has been shown to be specific for the demonstration of phospholipids containing double bonds; hydrogenation of the unsaturated phospholipids stops the reaction (Chayen, 1968). Similarly, when tissue sections are exposed to bromination, the saturation of the double-bonds prevents the sections from reacting (Bitensky, 1962).

Qualitatively the acid haematein technique showed a greater degree of staining in rheumatoid synovial lining cells than in nonrheumatoid cells (Fig. 1). This was confirmed by microdensitometry which showed approximately three times as much stain in the rheumatoid synoviocytes. The difference in the amount of reaction product, per cell, between rheumatoid and nonrheumatoid specimens was highly significant $(\mathrm{P}<0.001)$.

Sections of synovial membrane were subjected to methanol-chloroform to chemically alter the binding 
of cellular phospholipids to protein. In the nonrheumatoid lining cells this procedure caused a threefold increase in the specific reaction for phospholipid so that three of the four nonrheumatoid synovial membranes stained with the same intensity as found in rheumatoid synoviocytes. The fourth specimen (1701) had a high degree of stain in the untreated sections. It may be relevant that this patient had a 2-year history of recurrent locking of the knee, and at operation there was local osteochondritis around the meniscal fragment.

Rheumatoid lining cells receiving the same treatment lost the specific staining material fairly rapidly. Only specimen 1819 showed any increase in staining. This patient was the only one of this group who was being treated with prednisolone $(5 \mathrm{mg} /$ day). It is known that such glucocorticoids stabilize membrane structure (Weissmann, 1971) and this may account for the small amount of bound phospholipid in this synovial membrane which could be disclosed by treatment with methanol-chloroform.

These findings are strong evidence for the hypothesis that alteration in protein-phospholipid binding occurs in the membranes of rheumatoid synoviocytes. Evidence suggests that in rheumatoid arthritis not only is there alteration in the function of the synovial membrane but also that the subcellular membranes of the synoviocytes may be abnormal. Thus it has been known for many years that the rheumatoid synovial membrane is more permeable to plasma proteins (Sundblad et al., 1961; Nettlebladt et al., 1963). This increased permeability accounts for the increased concentration in the joint fluid of such proteins as caeruloplasmin (Niedermeier, 1965).

It has been shown that the amount of sulphurcontaining amino acids in the reduced state (-SH state) in rheumatoid synoviocytes is significantly greater than in the equivalent nonrheumatoid cells (Butcher et al., 1973). Since the disulphide moiety can play a large part in maintaining the threedimensional structure of proteins, the increase in the -SH content of the rheumatoid synoviocytes implies a loss of protein stability in these cells. As cellular membranes can contain up to $60 \%$ protein (Lenaz, 1974), alterations in the proportion of the sulphur-containing amino acids in the reduced form may play a part in determining membrane stability, and therefore membrane function. This premise is supported by the finding of significantly increased lysosomal permeability in human rheumatoid synoviocytes (Chayen et al., 1971a). In addition, the activity of 5 -nucleotidase, an enzyme bound to the plasma membrane, is increased in rheumatoid synoviocytes (Farr et al., 1973). In another system, Chayen et al. (1971b) found a strong correlation between the activity of this enzyme and oedem Thus this finding is consistent with the idea that the lining cells have very permeable plasma membranes. which may explain the increased permeability of the rheumatoid membrane to plasma proteins.

The unmasking of protein-bound phospholipids in rheumatoid synoviocytes is further evidence of alteration in the membrane structure in these celle Consequently it now appears that both the prote and the lipid moieties of the membranes are alteret in rheumatoid synoviocytes.

We are grateful to Mr B. Cashman, FRCS, and Mr A. Catterall, FRCS, for supplying the specimens, We are glad to acknowledge a grant towards this work from the Medical Research Council, and the support of the Arthritis and Rheumatism Councip for Research.

\section{References}

Baker, J. R. (1946). The histochemical recognition of lipin® Quarterly Journal of Microscopical Science, 87, 441-47. Baker, J. R. (1947). Further remarks on the histochemicat recognition of lipine. Quarterly Journal of Microscopica Science, 88, 463-465.

Bitensky, L. (1962). Histochemical studies on experimengif induced liver tumours in rats. PhD thesis, Universit London.

Butcher, R. G., Bitensky, L., Cashman, B., and Chayer (1973). Differences in the redox balance in human rheum toid and non-rheumatoid synovial lining cells. Beiträge zu하 Pathologie, 148, 265-274.

Chapman, D., and Quinn, P. J. (1976). A method for th modulation of membrane fluidity: homogeneous catalytR hydrogenation of phospholipids and phospholipid-water model biomembranes. Proceedings of the National Academ of Sciences of the USA, 73, 3971-3975.

Chayen, J. (1968). The histochemistry of phospholipids and its significance in the interpretation of the structure of cellp. Cell Structure and its Interpretation, p. 149. Ed. by S. Mo McGee-Russell and K. F. A. Ross. Arnold, London.

Chayen, J., and Bitensky, L. (1968). Multiphase chemistry of cell injury. The Biological Basis of Medicine, p. 337. Ed. by E. E. Bittar and N. Bittar. Academic Press, London and New York.

Chayen, J., Bitensky, L., Butcher, R. G., and Cashman, (1971a). Evidence for altered lysosomal membranes io synovial lining cells from human rheumatoid joints. Beiträge zur Pathologie, 142, 137-149.

Chayen, J., Bitensky, L., and Ubhi, G. S. (1971b). Quantitar. tive cytochemical studies on psoriasis and the effect of certain drugs. Clinical Trials Journal, 2, 35-45.

Farr, M., Kendall, M. J., Shuttleworth, R., Meynell, M. J. and Hawkins, C. F. (1973). Source and significance of 5-nucleotidase in synovial fluid. Annals of the Rheumatio

Diseases, 32, 326-330.
Fieser, L. F., and Fieser, M. (1953). Organic Chemistry 2nd ed., p. 939. Harrap, London.

Folch, J., Ascoli, I., Lees, M., Meath, J. A., and Le Barori F. N. (1951). Preparation of lipide extracts from brain tissue. Journal of Biological Chemistry, 191, 833-841.

Henderson, B. (1977). Quantitative cytochemical studies of rheumatoid arthritis. PhD thesis, Brunel University. 
Kiefer, G. (1970). The role of the mounting medium in U.V. microphotometry. Introduction to Quantitative Cytochemistry, Vol. 2, p. 295. Ed. by G. L. Wied and G. F. Bahr. Academic Press, New York and London.

Lenaz, G. (1974). Lipid-protein interactions in the structure of biological membranes. Sub-Cellular Biochemistry, 3, 167-248.

Loveridge, N., Bloom, S. R., Welbourn, R. B., and Chayen, J. (1974). Quantitative cytochemical estimation of the effect of pentagastrin $(0.005-5 \mathrm{pg} / \mathrm{ml})$ and of plasma gastrin on the guinea-pig fundus in vitro. Clinical Endocrinology, 3, 389-396.

McCabe, M., Cunningham, G. J., Wyatt, A. P., and Taylor, G. W. (1965). Vein grafts. Changes in phospholipid structure due to storage in saline solution. Lancet, 2, 109-111.

Nettelbladt, E., Sundblad, L., and Jonsson, E. (1963). Permeability of the synovial membrane to proteins. Acta Rheumatologica Scandinavica, 9, 28-32.

Niedermeier, W. (1965). Concentration and chemical state of copper in synovial fluid with blood serum of patients with rheumatoid arthritis. Annals of the Rheumatic Diseases, 24, 544-548.

Niles, N. R., and Barnhouse, D. L. (1967). The acid haematein stain and myocardial damage. Archives of Pathology, 83, 407-410.

Niles, N. R., Bitensky, L., Braimbridge, M. V., and Chayen, J. (1966). Histochemical changes related to oxidation and phosphorylation in human heart muscle. Journal of the Royal Microscopical Society, 86, 159-166.

Ropes, M. W., Bennett, G. A., Cobb, S., Jacox, R., and Jessar, R. A. (1959). Diagnostic criteria for rheumatoid arthritis. Annals of the Rheumatic Diseases, 18, 49-51.

Sundblad, L., Jonsson, E., and Nettelbladt, E. (1961). Permeability of the synovial membrane to glycoproteins. Nature, 192, 1192.

Weissmann, G. (1971). The effect of corticosteroids, especially on lysosomes and biomembranes. Rheumatoid Arthritis, Pathogenetic Mechanisms and Consequences in Therapeutics, p. 577 . Ed. by W. Müller, H.-G. Harwerth, and K. Fehr. Academic Press, London and New York. 